\title{
The influence of hulless barley on selected physical and chemical parameters in broiler chicken femur bones
}

\author{
M. Kwiecień \\ Agricultural University of Lublin, Institute of Animal Nutrition \\ Akademicka 13, 20-950 Lublin, Poland
}

\begin{abstract}
The study was performed on 162 Cobb broiler chickens, divided into 3 groups, 54 birds each. Three experimental diets were prepared, each as starter, grower and finisher. The control diet (C) was wheat-based, while experimental diets contained $450 \mathrm{~g} / \mathrm{kg}$ of hulless or hulled barley. Diets were fed ad libitum. On day 42 of age 4 males and 4 females from each group were sacrificed and the physicochemical parameters in femurs measured. Hulless barley significantly reduced the circumference of femoral bones, while increasing their fracture resistance. The ratio of breakage force to bone mass and circumference showed significant resistance improvement in the group fed hulless barley. Hulless barley significantly increased the $\mathrm{Ca}$ and $\mathrm{Mg}$ content in the femoral bones.
\end{abstract}

KEY WORDS: broiler, hulless barley, femur composition, physical traits

\section{INTRODUCTION}

A factor limiting the use of traditional barley grain in poultry feeding is its high content of crude and dietary fibre, which averages about 5 and $17 \%$, respectively, and high percentage of water soluble nonstarch polysaccharides (NSP). In hulless varieties of barley, the crude fibre content is lower, yet a high NSP content, mainly $1,3: 1,4-\beta$-glucan, is still a problem. A high concentration of $\beta$-glucans impairs digestion, increases the viscosity of intestinal contents and impedes nutrient absorption (Huyghebaert and De Groote, 1995; Smits and Annison, 1996). The impediment also concerns the mineral elements essential for bone mineralization. Lowering the amount of available minerals may result in changes of bone properties.

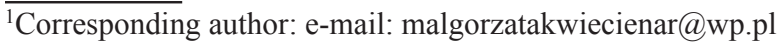


The aim of the study was to determine the influence of substituting hulless barley for the hulled variety on the mineral composition and breaking strength of the femur bone in broiler chickens.

\section{MATERIAL AND METHODS}

The study was performed on 162 Cobb broiler chickens kept in cages up to 42 days of age under standard environmental conditions. One-day-old chickens were randomly assigned to 3 groups, 54 birds each. Three experimental diets were prepared, each as starter, grower and finisher. The control diet (C) was wheat-based, while experimental diets contained $450 \mathrm{~g} / \mathrm{kg}$ of hulless or hulled barley. Birds were fed starter diets from day 1 to 14, grower from 15 to 35, finisher from 36 to 42 day of life, respectively. The content of crude fibre in diets, analysed with the use of standard methods, was 3, 2.3 and 3.1\% in starter and $2.8,2$ and $2.9 \%$ in grower/finisher, respectively. At the end of the experiment, 4 males and 4 females of a body weight approaching the mean for both sexes were randomly selected from each group, slaughtered and their femoral bones excised and cleaned from all exterior tissues. Femoral bones were weighed and their length, circumference at $1 / 2$ length and breaking strength were measured with the use of an INSTRON 4302 apparatus. Then the bones were dried, defatted, ashed and ash content was determined as well as the $\mathrm{Ca}, \mathrm{P}$ and $\mathrm{Mg}$ content in ash. The content of $\mathrm{Mg}$ and $\mathrm{Ca}$ was determined by atomic absorbtion spectrophotometry, $\mathrm{P}$ by photometry on a Helios Delta apparatus. Data were analysed by two-way analysis of variance using a programme developed by the Department of Statistics of the Agricultural University in Lublin.

\section{RESULTS}

All measured bone parameters were significantly greater in males than in females $(\mathrm{P}<0.01)$. Hulless barley had no significant effect on mass and length of the femoral bones, yet it had a negative effect on bone circumference and positive one on bone resistance to shear stress (Table 1). Thus the ratio of breakage force to bone mass, circumference and length as well as the $\mathrm{Ca}(\mathrm{P} \leq 0.05)$ and $\mathrm{Mg}$ content $(\mathrm{P} \leq 0.01)$ in bone ash were higher in the group fed the diet with hulless barley than in the groups fed diets with wheat or hulled barley.

\section{DISCUSSION}

Although the cereal species did not significantly influence the mass and length of femoral bones, in the group fed hulled barley the bone length was greater by $2.6 \%$, 
on average, as compared with the groups receiving diets with wheat or hulless barley. The values obtained in the present study were lower than those reported by Janocha et al. (2004). The femoral bone circumference of the chickens fed the diet with hulless barley was smaller by $7.7 \%$ than in birds receiving wheat and by $5 \%$ than in birds fed hulled barley. The last group showed the highest bone resistance, however.

Table 1. Parameters of broiler chickens' femur bones

\begin{tabular}{|c|c|c|c|c|c|}
\hline \multirow[b]{2}{*}{ Parameter } & \multirow[b]{2}{*}{ Sex } & \multicolumn{3}{|c|}{ Dietary treatment } & \multirow[b]{2}{*}{$\bar{x} \operatorname{sex}$} \\
\hline & & control & $\begin{array}{c}\text { hulless } \\
\text { barley }\end{array}$ & $\begin{array}{l}\text { hulled } \\
\text { barley }\end{array}$ & \\
\hline \multirow[t]{3}{*}{ Weight, $g$} & $\hat{0}$ & 4.52 & 4.20 & 4.68 & $4.47^{\mathrm{A}}$ \\
\hline & 우 & 3.21 & 3.15 & 3.5 & $3.37^{\mathrm{B}}$ \\
\hline & $\overline{\mathrm{x}}$ group & 3.87 & 3.67 & 4.22 & \\
\hline \multirow[t]{3}{*}{ Length, mm } & 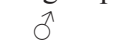 & 72.0 & 70.8 & 71.3 & $71.3^{\mathrm{A}}$ \\
\hline & 우 & 64.5 & 66.0 & 69.1 & $66.5^{\mathrm{B}}$ \\
\hline & $\overline{\mathrm{x}}$ group & 68.3 & 68.4 & 70.2 & \\
\hline \multirow[t]{3}{*}{ Circumference, $\mathrm{mm}$} & O & 33.0 & 30.5 & 31.8 & $31.8^{\mathrm{A}}$ \\
\hline & q & 28.3 & 26.0 & 27.8 & $27.3^{\mathrm{B}}$ \\
\hline & $\overline{\mathrm{x}}$ group & $30.6^{\mathrm{a}}$ & $28.3^{\mathrm{b}}$ & $29.8^{\mathrm{ab}}$ & \\
\hline \multirow[t]{3}{*}{ Breaking strength, $\mathrm{N}$} & Oे & 119 & 123 & 82.1 & $108^{\mathrm{A}}$ \\
\hline & q & 57.6 & 67.4 & 71.1 & $65.4^{\mathrm{B}}$ \\
\hline & $\overline{\mathrm{x}}$ group & $88.3^{\mathrm{ab}}$ & $95.0^{\mathrm{a}}$ & $76.1^{\mathrm{b}}$ & \\
\hline \multirow{3}{*}{$\begin{array}{l}\text { Breaking strength/weight, } \\
\quad \mathrm{N} / \mathrm{g}\end{array}$} & $\hat{O}$ & 26.5 & 29.2 & 17.7 & $24.5^{\mathrm{A}}$ \\
\hline & q & 18.1 & 21.5 & 19.2 & $19.6^{\mathrm{B}}$ \\
\hline & $\overline{\mathrm{x}}$ group & $22.3^{\mathrm{AB}}$ & $25.3^{\mathrm{A}}$ & $18.4^{\mathrm{B}}$ & \\
\hline Breaking strength/length & o & 1.65 & 1.73 & 1.16 & $1.51^{\mathrm{A}}$ \\
\hline \multirow[t]{2}{*}{$\mathrm{N} / \mathrm{mm}$} & $q$ & 0.89 & 1.02 & 1.02 & $0.98^{\mathrm{B}}$ \\
\hline & $\overline{\mathrm{x}}$ group & $1.27^{\mathrm{ab}}$ & $1.37^{\mathrm{a}}$ & $1.09^{\mathrm{b}}$ & \\
\hline Breaking strength/ circumference & $\hat{\sigma}$ & 3.59 & 4.03 & 2.59 & $3.40^{\mathrm{A}}$ \\
\hline \multirow[t]{2}{*}{$\mathrm{N} / \mathrm{mm}$} & q & 2.04 & 2.59 & 2.56 & $2.40^{\mathrm{B}}$ \\
\hline & $\overline{\mathrm{x}}$ group & $2.61^{\mathrm{A}}$ & $3.31^{\mathrm{B}}$ & $2.57^{\mathrm{A}}$ & \\
\hline Crude ash, $\%$ & $\overline{\mathrm{x}}$ group & 57.5 & 57.4 & 57.4 & \\
\hline $\mathrm{Ca}, \mathrm{mg} / \mathrm{g}$ & $\overline{\mathrm{x}}$ group & $181^{\mathrm{a}}$ & $190^{\mathrm{b}}$ & $182^{\mathrm{a}}$ & \\
\hline $\mathrm{P}, \mathrm{mg} / \mathrm{g}$ & $\overline{\mathrm{x}}$ group & 236 & 235 & 235 & \\
\hline $\mathrm{Mg}, \mathrm{mg} / \mathrm{g}$ & $\bar{x}$ group & $12.8^{\mathrm{A}}$ & $13.9^{\mathrm{B}}$ & $13.2^{\mathrm{AB}}$ & \\
\hline
\end{tabular}

a,b - group means in rows or sex means in columns with different superscripts differ significantly a,b - at $\mathrm{P} \leq 0.05,{ }^{\mathrm{A}, \mathrm{B}}$ - at $\mathrm{P} \leq 0.01$

The experimental diets had a significant impact on bone mass, length and circumference, which were higher in the hulless barley group by $21-27 \%$. Although the crude ash content in the bones was similar, feeding the hulless barley diet increased the $\mathrm{Ca}$ and $\mathrm{Mg}$ concentration in ash. The content of $\mathrm{Ca}$ and $\mathrm{Mg}$ in feeds was sufficient to meet the chickens' requirements in terms of bone formation, 
however, it can be hypothesised that the hulless barley diet enhanced the retention of both minerals in bones. The values obtained for the femoral bone correspond to those reported by Janocha et al. (2004) regarding crude ash and calcium content, while the phosphorus content was substantially higher in the present study.

\section{CONCLUSIONS}

The substitution of wheat or hulled barley by hulless barley may have a positive impact on bone strength in broiler chickens.

\section{REFERENCES}

Huyghebaert G., De Groote G., 1995. The effect of specific enzymes on the MEn value and nutrient utilization of target feedstuffs in broiler and layer diets. Proceedings of $10^{\text {th }}$ European Symposium on Poultry Nutrition, Antalya (Turkey), pp. 176-192

Janocha A., Osek M., Klocek B., Milczarek A., Wasiłowski Z., 2004. The influence of the protein content and Hy-D premix on production effects and quality of bones in broiler chickens. Rocz. Nauk. Zoot., Suppl. No. 20, 181-184

Smits C.H.M., Annison G., 1996. Non-starch plant polysaccharides in broiler nutrition - towards a physiologically valid approach to their determination. World Poultry Sci. J. 52, 203-221

\section{STRESZCZENIE}

Wpływ jęczmienia nagoziarnistego na wybrane parametry fizyko-chemiczne kości udowych kurcząt brojlerów

Przeprowadzono doświadczenie na 162 kurczętach brojlerach Cobb, podzielonych na 3 grupy, po 54 ptaki w grupie. Przygotowano 3 diety, każdą jako starter, grower i finiszer. Dieta kontrolna zawierała pszenicę, podczas gdy diety doświadczalne uzupełniono $450 \mathrm{~g} / \mathrm{kg}$ jęczmienia oplewionego lub nagoziarnistego. Diety podawano do woli. W 42 dniu życia 4 koguty i 4 kurki z każdej grupy ubito i zmierzono niektóre parametry fizyczne i chemiczne kości udowych. Jęczmień nagoziarnisty istotnie wpłynął na zmniejszenie obwodu trzonu kości udowych i zwiększył jednocześnie wytrzymałość kości na złamanie. Odniesienie siły łamania do masy i obwodu kości wykazało istotną poprawę wytrzymałości w grupie żywionej dietą z jęczmieniem nagoziarnistym. Jęczmień nagoziarnisty zwiększył znacząco zawartość Ca i Mg w kościach udowych. 